\title{
Public policies and the insertion of old people in the labor market in Brazil
}

Andrea Toshye Satol ID Selma Lancman' $\mathbb{D}$

\section{Abstract}

Objective: Discuss how Brazilian public policies aimed at old people address the right of the old people to decent work, and the promotion of their insertion and maintenance at work. Method: Bibliographic research was carried out to analyze the Brazilian public policies aimed at old people. In order to deepen the analysis of these policies, they were consulted in full on Brazilian government websites. The data was analyzed based on content analysis. Results: Among the public policies aimed at the old people those having some type of work-related disposition provision are: the National Policy for Old People, State Policy for Old People, Statute of the Elderly, and National Health Policy for Old People. The work-related propositions were categorized into: I. Creation of working conditions for old people; II. Preventing discrimination and encouraging the hiring of old people; III. Continuing education for old people; IV. Retirement; V. Work as a choice. Conclusion: Over time, Brazilian public policies aimed at old people have been improving the approach to decent work, and the promotion of the insertion and maintenance of old people in their work. However, there is still a lack of better advances and clarifications about the guidelines and recommendations related to work for old people, emphasizing the importance of work contexts considering the conditions and organizations impacting the possibility of insertion and maintenance of old people at work.

\footnotetext{
Faculdade de Medicina da Universidade de São Paulo, Departamento de Fisioterapia, Fonoaudiologia e Terapia Ocupacional. São Paulo, SP, Brasil.

Funding: Fundação de Amparo à Pesquisa do Estado de São Paulo (FAPESP). Projeto Temático FAPESP número 2014/25985-2. Tipo de subsídio: reserva técnica.

The authors declare there are no conflicts of interest in relation to the present study.

Keywords: Aging. Public Policies. Occupation Health. 


\section{INTRODUCTION}

As the Brazilian population ages, there is a greater social participation of the old people (those who are 60 years or older). This occurs even in work activities $^{1-4}$.

In $1977,4.9 \%$ of workers in the labor market were old people, showing a growing trend. In 1998, this number rose to $9 \%$, and the expectation is that in 2020 about $13 \%$ of the employed population in the country is of old people ${ }^{5}$. These predictions have been sustained for several reasons.

In Brazil, old people tend to continue working to supplement their family income as their retirement are often the only income for them and/or their families, and it is not enough for them to live $e^{3}$. Added to this are the legal changes which set more years to be worked or to contribute to Social Security before retirement ${ }^{3-4}$. Some people also keep working for the meaning and importance they give to work. These can be related to the needs of social interaction, to remain active, productive, and even to spend their idle time ${ }^{6,7}$.

In addition, the Brazilian Social Security reform ${ }^{8}$ was approved at the end of 2019 and determined to cut and postpone some benefits. Thus, although the changes occur gradually based on a transition rule, the minimum age and working time required for retirement are increasing in Brazil, which is likely to result in an even greater number of old people who will need to remain in the labor market.

Given these data, it is noted that the old person will want and/or need to keep working more and more. For this, there may be challenges ${ }^{4}$. One of them relates to the work organization. This is often designed for young workers. This can be an impediment to the permanence of the others, considering that structural unemployment will lead the old person to compete for job positions with younger workers ${ }^{4,6}$.

Another challenge refers to ageism, a term used to define a type of prejudice related to age that can generate a set of negative or positive attitudes towards aging $^{2}$, favoring or disfavoring the inclusion and maintenance of the old person in the labor market.

On the one hand, the old person has potential for work due to their experience, which would lead to their appreciation ${ }^{6,9}$. On the other hand, it is noted that in general and especially in less qualified jobs (with greater physical demands instead of experience and accumulation of knowledge), there is a tendency of devaluation of the old worker because it is considered that they have reduced skills to work' ${ }^{9}$.

The main justification for this consideration is that the aging process, although quite heterogeneous, involves the presence of biological declines resulting in decreased intrinsic capacity ${ }^{2,9}$. However, this justification is debatable, since studies claim that declines in aging generally result in a negative impact on intrinsic capacity, but not necessarily on functional and work capacity ${ }^{10,11}$.

The term "intrinsic capacity" refers to an individual's physical, intellectual, and psychological capacities, whereas "functional capacity" refers to the ability to perform various tasks resulting from the interaction between intrinsic capacity and the possibilities offered by theenvironment including the possibility of using auxiliary devices ${ }^{11}$. The "work capacity" relates to the type of work that the person does, referring to the intrinsic capacity of interaction with the organizational culture and the work environment for carrying out labor activities ${ }^{10}$.

Therefore, the adaptability of the old person at work does not depend only on their individual characteristics, but also on the conditions and organization of work. The work organization corresponds to its content, division of labor, hierarchical levels, production norms and procedures, established goals and pace, interpersonal relations; work conditions refer to the materials and physical facilities used to carry out the work ${ }^{12}$.

The current labor conditions have offered few possibilities for workers to adapt for a variety of reasons. The main one is the process of precarization of work, which has been in place since the 1990s. Precarization of work can be defined as a degradation 
process including aspects like the deregulation of the job, deterioration of the work conditions, extension of workday, reduction of the wages, increased social deprotection, diffusion of physical and/or mental suffering as inherent to work, structural unemployment, among other ${ }^{6,13}$.

The social security changes did not take into account the culture of ageism, the need for changes in the work organization, and the global precarization process that the country was already going through. These factors can make it difficult and even make it impracticable to include and keep the old people in the job. Therefore, there is a need for strategies at various levels to prolong the time of old workers at work.

Public policies aimed at the old people were implemented as the country began to reverse its age pyramid. These policies are not always sufficient for the demands of the population. However, they are essential for the support of old workers, and it is believed that they will allow to guarantee the right to decent work and promote the insertion and maintenance of the old people at work ${ }^{4}$.

Decent work, according to the International Labor Organization (ILO) ${ }^{14}$, refers to the productive work to provide a dignified life for the people who do it. This work is carried out under conditions of freedom, equity, and safety, without discrimination. Also according to the ILO, there are some indicators to define decent work, such as job opportunities, adequate income and productive work, decent working hours, combination of work, personal and family life, stability and safety at work, equal opportunities and treatment at work, safe work environment, social security and social dialogue, and representation of workers and employers ${ }^{14}$.

The present study aimed at discussing how Brazilian public policies aimed at old people address the right of the old people to decent work, and the promotion of their insertion and maintenance at work. In addition, it aimed to deepen, more specifically, how these policies evolved in the search for the creation of working conditions, fostering non-discrimination of this population in work environments, creation of programs for job offers, for training/continuing education, and for preparation for retirement.

\section{METHOD}

This is a documentary research of a qualitative nature. Initially, a bibliographic search of studies dealing with Brazilian public policies directed at the old people was carried out at Portal de Periódicos Capes, and published in article format related to the Brazilian public health area in the period between 2000 and 2020, available in full in Portuguese. The following search terms were used in isolation: "policies and old people", "public policies of old people", "legislation for the old people", "public policies and aging".

We found a total of 416 articles. Of these, we excluded the repeated ones, and those not having Brazilian public policies directed to the old people as their central theme, or those with some specificity in some theme (for example, an article dealing with public policies directed only to the institutionalized old people). Thus, 67 articles were selected. After reading the abstracts, we considered that there was a redundancy of information. Therefore, we selected the articles that dealt more widely with the targeted content. Thus, 11 articles were selected.

These articles were the basis for a survey on the main Brazilian public policies directed to the old people listed in the literature and the focus of the present study. Therefore, the analysis of these articles is not the central point of the study.

To deepen the analysis of these policies, we consulted them in full on Brazilian government websites such as Planalto, Virtual Health Library of the Ministry of Health, Federal Senate, Chamber of Deputies, Ministry of Social Security and Social Assistance.

The data was analyzed based on the content analysis ${ }^{15}$, with an exhaustive reading of the policies indicated in the articles and the apprehension of differences and common points which are different and/or complementary among them regarding the right of the old people to decent work and promotion of insertion and maintenance at work. 


\section{RESULTS}

In 1988, the Federal Constitution $(\mathrm{CF})^{16}$ was established, and ensured the right to life and citizenship to the old people. The CF deals with work for the general population, stating that it is a social right, being forbidden differences in wages, exercise of functions, and hiring criterion due to sex, age, color or marital status.

In 1994, the National Policy for Old People (PNI) was created - Law $8,842^{17}$. The PNI aims to create conditions to promote autonomy, integration and effective participation of the old person in society with the implementation of actions in several areas, among them work. This Policy defines that government actions should be proposed to ensure mechanisms to prevent discrimination of the healthy old person regarding their participation in the labor market, and that retirement preparation programs are created.

Subsequently, the State Policy of the Elderly (PEI) - State Law 9,892, of 1997 (São Paulo/SP), repealed by Law 12,548 of $2007^{18}$, was established to guarantee the necessary conditions for the old people to continue their full exercise of citizenship. PEI suggests the incentive to provide labor therapy and occupational therapy services and voluntary work programs to the old person, and prepare them for retirement. It also recommends offering professional training and retraining aimed at inserting the old peple into the labor market, avoiding any type of discrimination.
In 2003, the Statute of the Elderly (EI) was instituted - Law $10,741^{19}$ - to extend the rights foreseen in PNI, also regarding labor. The EI states that professionalization and work are basic rights of the old people, being respected their physical, intellectual, and psychic conditions in the professional activity. Said Statute states that discrimination is prohibited in hiring old people in any work, and that preference will be given to those of higher age in the event of a tie in public tender. It also suggests encouraging private companies to hire old people and create retirement preparation and professionalization programs for this population, taking advantage of their potentials and skills for regular and paid activities.

In 2006, the National Health Policy for Old People (PNSPI) was promulgated - Ordinance 2,528 ${ }^{20}$ - which aims to recover, maintain, and promote the autonomy and independence of the old person with collective and individual health measures. PNSPI proposes the implementation of measures to prepare for retirement, eliminate discrimination in the labor market, create conditions allowing the insertion of the old person in the socioeconomic life of the communities and for the survey of the old people who returned to work in order to identify the conditions in which they operate in order to prevent abuse and exploitation.

The proposals of work-related policies for the old people were categorized and pointed out in Table 1.

Table 1. Relation between work-related propositions and policies aimed at the old people.

\begin{tabular}{|l|c|c|c|c|}
\hline Policies & $\begin{array}{c}\text { National Policy for } \\
\text { Old People (PNI) }\end{array}$ & $\begin{array}{c}\text { State Policy for } \\
\text { Old People (PEI) }\end{array}$ & $\begin{array}{c}\text { Statute of the } \\
\text { Elderly (IE) }\end{array}$ & $\begin{array}{c}\text { National Health } \\
\text { Policy for Old } \\
\text { People (PNSPI) }\end{array}$ \\
\hline $\begin{array}{l}\text { I. Creation of working } \\
\text { conditions for old people }\end{array}$ & $\mathrm{X}$ & $\mathrm{X}$ & $\mathrm{X}$ \\
\hline $\begin{array}{l}\text { II. Preventing discrimination } \\
\text { and encouraging the hiring of } \\
\text { old people }\end{array}$ & & $\mathrm{X}$ & $\mathrm{X}$ \\
\hline $\begin{array}{l}\text { III. Continuing education for } \\
\text { old people }\end{array}$ & $\mathrm{X}$ & $\mathrm{X}$ & $\mathrm{X}$ & $\mathrm{X}$ \\
\hline IV. Retirement & & $\mathrm{X}$ & & \\
\hline V. Work as a choice & & & \\
\hline
\end{tabular}




\section{DISCUSSION}

Initially, from 1974 to 1994, government actions aimed at the old people were of an assistance nature or were within broader policies ${ }^{21}$. In 1994, the PNI was created and brought advance to the legislation, since it was the first policy specific for this population, which did not have an assistance nature and which sought to ensure the social rights of the old people in various areas of life. From there, other policies were being implemented. Among them, EI was also a milestone for proposals aimed at the old people considering the scope of the issues related to them.

As public policies were created, they started to include deliberations aimed at ensuring the rights of the old people in different areas of life, including work. Thus, this population went from passive agents of these policies to becoming more and more prominent before society.

The fact of the policies considering the work of the old people is a progress, since this was not thought in previous legislations, as Consolidation of Labor Laws (CLT) ${ }^{22}$ - Decree No 5,452 of 1943. This last one does not present provisions on work for this age group, although it presents protection for woman work, for example.

The recommendations presented are in line with some of the proposals of the World Health Organization (WHO) $)^{23}$ for Active Aging, which refers to the aging process seeking to improve the quality of life. According to this organization, the maintenance of old people at work can be an indication and element to promote health and quality of life to the population. Thus, it suggests the dynamic participation of the old people in the activities of economic development, work, and volunteering, according to their individual needs, preferences, and skills.-

Thus, the $\mathrm{WHO}^{23}$ recommends actions to provide permanent learning, the dissemination of the positive image of aging, and poverty reduction. With regard to formal work, it suggests that programs and policies are implemented to allow old people to participate in the labor market. As an example, it mentions the elimination of age discrimination in hiring, and the maintenance of older workers in the companies.

\section{Creation of working conditions for old people}

The introduction of technological innovations, the outsourcing of services, increased informal employment relations, and changes in the organization of work have generated an increase in labor and productivity requirements. These can be verified by increased pace of work and the burden of responsibility, reduced rest, and extended intervals in working hours, increased underemployment, among others ${ }^{6,13,24}$.

Work contexts like these can lead to the triggering of physiological, psychological, and behavioral responses in workers of all ages, with the possibility of decreased ability to work, the onset of diseases/ symptoms, and retirement or retirement on disability.

However, old workers may be more susceptible to health problems due to senescence and to the fact that work-related diseases are a cumulative and progressive process that can take years to manifest ${ }^{10,12}$.

Thus, the adequacy of the conditions and organization of work are indispensable to promote health and quality of life, as well as the inclusion and permanence of the old person at work. This adequacy can be from digital inclusion, often considered a specific barrier for the old people to the adequacy of labor relations, indispensable to workers of all ages ${ }^{9,12}$.

Although the adequacy of conditions and work organization are an essential recommendation, it is still little addressed in policies aimed at the old person, having been mentioned only in $\mathrm{PNSPI}^{20}$. However, this policy does not provide indications of what these conditions should be, and do not address the organizational issue of the companies. Therefore, this is a relevant point that should be improved.

\section{Preventing discrimination and encouraging the hiring of old people}

The above-mentioned contexts tend to generate an even more competitive market in which the old person often suffers disadvantages ${ }^{24}$. Most often, unemployment affects these workers who are replaced by younger workers because they are considered to have higher production capacity and lower costs ${ }^{4,9}$. 
In addition, the old people are often considered to have limited performance, especially in activities with high physical demands or characterized by rapid technological changes ${ }^{9,24}$. Although studies claim that aging is not synonymous with lower productivity, negative stereotypes are attributed to the old person because aging is considered to refer only to a process of degeneration. Thus, it is noted that ageism becomes present, disfavoring the insertion and maintenance of the old person in the labor market ${ }^{2,25}$.

Studies indicate that discrimination with old people can result both in their non-hiring and their dismissal, and therefore it is necessary to combat the negative stereotypes that can lead to the exclusion of old workers ${ }^{2,26}$. In this sense, it is important to implement measures to prevent discrimination and privilege the old people in the hiring of public and private companies, since this can be a way to balance the competitiveness of the labor market and fight the stigma on the old person. This measure is recognized by all the policies that have been studied here.

\section{Continuing education for old people}

Due to stereotypes, old workers often tend to be considered obsolete, less productive, resistant to changes, and not motivated. It generates companies lack of interest in investing in these workers, as they believe little of these costs will be returned?

Studies show that old people receive fewer incentives, such as offers to participate in permanent and continuing education programs than other age groups ${ }^{10}$. This factor could explain part of the disadvantage suffered by the old people in the labor market, since the productivity potential can be impaired by the less exploited and/or not updated skills that could be corrected with educational programs?

In addition, these programs may have an even greater importance for the old people when considering that they may have cognitive declines resulting from the aging process ${ }^{3,9}$. Thus, as pointed out by $\mathrm{PEI}^{18}$ and $\mathrm{EI}^{19}$, professional training and recycling programs can contribute to the insertion and maintenance of the old person in the labor market ${ }^{24}$. $\mathrm{EI}^{19}$ also suggests that the potentials of the old people are used for work activities. Thus, the potentialities of old workers must be balanced with the difficulties in performing the work.

Of course, each worker will have different potentialities for work. However, in general, one of the main strengths of old workers is related to their know-how, i.e., experience arising from the practical or technical experience accumulated over the years of work ${ }^{6,12}$.

In addition to know-how, it is understood that aging can favor workers with the development of other skills such as diligence, independence, loyalty to the company, empirical and specific knowledge about the company, managerial skills, critical thinking and judgment, communication, responsibility and social competence, and awareness for safety and quality at work ${ }^{2,9,24}$.

Therefore, the importance of adjustments in the work organization is emphasized again, so that they take advantage of the skills of the old people and minimize the declines ${ }^{12}$. In addition, younger workers generally have other types of skills such as ease of dealing with new technologies, willingness to learn, health, and physical vigor. Thus, the exchange of experience between workers of different ages can be positive for companies, as there is a wider range of skills to be used ${ }^{2}$.

\section{Retirement}

The interruption of work activities can be experienced in different ways by each person. However, studies indicate that retirement can mean more than the interruption of work, involving identity crises, confused and ambivalent feelings mobilizing anxiety, mood alternation, psychosomatic diseases, and diverse fears. In this sense, retirement preparation programs can facilitate this process if the person can prepare when they are still working ${ }^{27,28}$.

The implementation of retirement preparation programs was addressed by all policies analyzed in the present study. These programs can be important for those who are close to retiring, as stopping to 
work can lead to a break in everyday life, and these programs can assist the old people in life projects?

\section{Work as a choice}

It is considered that there was no greater clarity about this item in the policies analyzed. However, it was understood that the programs of voluntary work and provision of work therapy and occupational therapy services proposed by $\mathrm{PEI}^{18}$ are an alternative form of work which the old person does for interest/ choice, and not a formal work that is driven by a need, for example, economic need.

Old people are often retired. Retirement can generate both difficulties in making use of the time that was used to work and isolation from the lack of contact with colleagues and the work environment. At the same time, retirement can enable the development of new alternative activities and hobbies $^{26}$.

Thus, these PEI proposals can contribute to answer the aforementioned questions arising from retirement or serve as a complement to the activities of the old person, especially when considering that this person gives a positive meaning to the work ${ }^{7}$.

But if work is relevant for the old person as a matter of financial gain, than voluntary work makes no sense. If the old person wishes to keep working to feel useful or to maintain social relations, this same work can possibly make sense.

It should be worth noting that the $\mathrm{WHO}$ considers that voluntary work should be acknowledged, and the opportunity given to the old people ${ }^{1,23}$. In addition, there is an indication that occupational therapy can contribute to the insertion and permanence of the old people in various daily activities, including work ${ }^{29}$.

Finally, it should be mentioned that the present study presents the limitation of addressing the subject of public policies and work for the old people in a comprehensive way without the possibility of considering singular cases, and with the risk of the propositions made here not being in line with certain groups of old workers. On the one hand, this scope allows an overview of the proposals related to work for the old person within the Brazilian public policies. On the other hand, it brings the limitation of deepening the subject addressed generating a certain superficiality to the study.

\section{CONCLUSION}

Over time, Brazilian public policies aimed at old people have been improving the approach to decent work, and the promotion of the insertion and maintenance of old people in their work. This occurred with the propositions aimed at protecting the rights and stimulating the work for old people.

It is noted that the PNI, the first policy specifically aimed at the old person, dealt with the work area in a more introductory way, proposing actions aimed only at fighting discrimination and preparing for retirement. The policies afterwards (PEI, EI e PNSPI) maintained these recommendations and added others such as the creation of continuing education programs to encourage companies to hire old people, and the provision of other types of work such as voluntary work. In addition, it was also suggested to create working conditions for the old people.

It is believed that these proposals can contribute to decent work and to the insertion and maintenance of the old person in this work. However, there is still a lack of better advances and clarifications about the guidelines and recommendations related to work for old people, emphasizing the importance of work contexts considering the conditions and organizations impacting the possibility of insertion and maintenance of old people at work. ${ }^{30}$.

Edited by: Ana Carolina Lima Cavaletti 


\section{REFERENCES}

1. Organização Mundial da Saúde. Active Ageing: a Police Framework. Genebra: WHO; 2002 [cited 2020 may 15]. Available from: http://apps.who. int/iris/bitstream/10665/67215/1/ WHO_NMH_ NPH_02.8.pdf

2. França LHFP, Siqueira-Brito AR, Valentini F, Vasques-Menezes I, Torres CV. Ageísmo no contexto organizacional: a percepção de trabalhadores brasileiros. Rev Bras Geriatr Gerontol. 2017;20(6):765-77.

3. Raymundo TM, Castro CSS. Análise de um programa de treinamento de trabalhadores mais velhos para o uso de tecnologias: dificuldades e satisfação. Rev Bras Geriatr Gerontol. 2019;22(5):e190039.

4. Paolini KS. Desafios da inclusão do idoso no mercado de trabalho. Rev Bras Med Trab. 2016;14(2):177-82.

5. Queiroz VS, Ramalho HMB. A Escolha ocupacional dos idosos no mercado de trabalho: evidências para o Brasil. EconomiA. 2009;10(4):817-48.

6. Lancman S, Sznelwar LI, Jardim TA. Sofrimento psíquico e envelhecimento no trabalho: um estudo com agentes de trânsito. Rev Ter Ocup. 2006;17(3):129-36

7. Ladeira MM, Costa DVF, Ferreira VCP, Nascimento RP, Costa MPC. Significado do trabalho para o idoso: um estudo exploratório. Rev Vianna Sapiens. 2017;8(1):71-102.

8. Brasil. Emenda Constitucional no 103, de 12 de novembro de 2019. Altera o sistema de previdência social e estabelece regras de transição e disposições transitórias. Diário Oficial da União. 13 nov. 2019.

9. Neri AL. Envelhecer bem no trabalho: possibilidades individuais, organizacionais e sociais. Terceira Idade. 2002;13(24):7-27.

10. Martinez MC, Latorre MRDO, Fischer FM. Capacidade para o trabalho: revisão de literatura. Ciênc Saúde Colet. 2010;15(sup.1):1553-61.

11. Organização Mundial da Saúde. Relatório mundial de envelhecimento e saúde. Genebra: WHO; 2015 [cited 2020 May 08]. Available from: http:// sbgg.org.br/wp-content/uploads/2015/10/OMSENVELHECIMENTO-2015-port.pdf

12. Sato AT, Barros JO, Jardim TA, Ratier APP, Lancman S. Processo de envelhecimento e trabalho: estudo de caso no setor de engenharia de manutenção de um hospital público do Município de São Paulo, Brasil. Cad Saúde Pública. 2017;33(10):e00140316.
13. Morosini MVGC. Precarização do trabalho: particularidades no setor saúde brasileiro. Trab Educ Saúde. 2016;14(Suppl. 1):5-7.

14. Organização Internacional do Trabalho. Trabalho Decente. Genebra: OIT; 1999 [cited 2020 July. 29]. Disponível em: https://www.ilo.org/brasilia/temas/ trabalho-decente/lang--pt/index.htm

15. Bardin L. Análise de conteúdo. Lisboa: Edições 70; 1977.

16. Brasil. Presidência da República. Casa Civil. Subchefia para Assuntos Jurídicos. Constituição da República Federativa do Brasil. Diário Oficial da União. 05 out. 1988.

17. Brasil. Lei n ${ }^{\circ} 8.842$, de 4 de janeiro de 1994. Dispõe sobre a Política Nacional do Idoso, cria o Conselho Nacional do Idoso e dá outras providências. Diário Oficial da União. 05 Jan. 1994.

18. São Paulo. Lei no 12.548 , de 27 de fevereiro de 2007. Consolida a legislação relativa ao idoso. Assessoria Técnico-Legislativa. 27 Fev. 2007.

19. Brasil. Lei no 10.741 , de $1^{\circ}$ de outubro de 2003. Dispõe sobre o Estatuto do Idoso e dá outras providências. Diário Oficial da União. 13 out. 2003.

20. Brasil. Portaria n 2.528, de 19 de outubro de 2006. Aprova a Política Nacional de Saúde da Pessoa Idosa. Diário Oficial da União. 20 out. 2006.

21. Braga SFM, Guimaraes LVM, Silveira RB, Calbino D. As Políticas Públicas para os Idosos no Brasil: a cidadania no envelhecimento. Diálogos Interdiscipl. 2016;5(3):94-112.

22. Brasil. Presidência da República. Casa Civil. Decretolei $n^{\circ} 5.452$, de $1^{\circ}$ de maio de 1943 . Aprova a Consolidação das Leis do Trabalho. Diário Oficial da União. 01 maio 1943.

23. Organização Mundial da Saúde. Envelhecimento ativo: uma política de saúde. tradução Suzana Gontijo. Brasília, DF: OPAS; 2005.

24. Teixeira RM, Andrade VLP. O idoso na busca por um lugar no mercado de trabalho. Cad Psicol. 2019;1(2):515-35.

25. Linhares LP, Aguiar CVN. Idoso no trabalho: a representação social de profissionais de recursos humanos. Rev Psicol Saberes. 2019;8(13):59-75.

26. Camarano AA, Carvalho DF, Kanso S. Saída precoce do mercado de trabalho: aposentadoria ou discriminação? Ciênc Saúde Colet. 2019;24(9):1-10. 
27. Pazzim TA, Marin A. Programas de preparação para aposentadoria: revisão sistemática da literatura nacional. Rev Bras Orientaç Prof. 2016;17(1):91-101.

28. Figueira DAM, Haddad MCL, Gvozd R, Pissinati PSC. A tomada de decisão da aposentadoria influenciada pelas relações familiares e laborais. Rev Bras Geriatr Gerontol. 2017;20(2):206-13.
29. Lancman S, Barros JO, Jardim TA. Teorias e práticas de retorno e permanência no trabalho: elementos para a atuação dos terapeutas ocupacionais. Rev Ter Ocup. 2016;27(2):101-8.

30. Rios MA, Vilela ABA, Nery AA. O trabalho e a saúde de açougueiros idosos: relato de casos em um mercado municipal. Rev Bras Geriatr Gerontol. 2017;20(5):643-9. 